Article

\title{
Price, Virtues, Principles: How to Discern What Inspires Best Practices in Water Management? A Case Study about Small Farmers in the Yucatan Peninsula of Mexico
}

\author{
Rafael R. Ramírez ${ }^{1, *}$, Leanne Seeliger ${ }^{2}$ and Filippo Di Pietro ${ }^{3}$ \\ 1 Department of Business and Sociology, University of Extremadura, 10071 Cáceres, Spain \\ 2 Department of Philosophy, Stellenbosch University, 7602 Stellenbosch, South Africa; seeliger@sun.ac.za \\ 3 Department of Financial Economics and Operations Management, University of Seville, \\ 41018 Sevilla, Spain; fdi@us.es \\ * Correspondence: rrobina@unex.es; Tel.: +34-685-152-904
}

Academic Editor: Luis A. Sañudo-Fontaneda

Received: 12 January 2016; Accepted: 12 April 2016; Published: 19 April 2016

\begin{abstract}
Improving water practices among small farmers in a water scarce area like the Yucatan Peninsula in Mexico is a complex task. Despite government attempts to enforce regulations and question the possibility of adjusting prices, the misuse of this scarce resource continues. Most farmers are, at best, motivated to aim for a minimum level of compliance, with very few striving to engage in best practices. This article seeks to make a proposal about the best drivers for inspiring best practices in an effort to improve the use of water management in the area. It proposes that a virtue ethics approach that explicitly focuses on the cultivation of an attitude of respect for water founded on three key principles (participation, hydrosolidarity and proactive engagement) is the best solution for Yucatan. This hypothesis is the result of developing a singular methodology based on Partial Least Squares (PLS), according to structural equation modeling (SEM), that could be replicated anywhere to ascertain which measures are best suited in a particular context. Using a small sample size, this research ascertains what is required to achieve best practices with regards to the management of water in that particular area.
\end{abstract}

Keywords: ethics; participation; hydrosolidarity; pro-active engagement; best practices; statistics

\section{Introduction}

Several management paradigms for addressing the ensuing global water crisis have emerged over the past century. Initially, a technocratic, efficient and depoliticized management process [1] coped with the increased urban populations, industrial development processes and the needs of large scale agricultural farming [2]. While this technical approach was very efficient at addressing water quality and quantity problems in the beginning, it was not capable of focusing on the increasingly complex nature of water management issues.

Integrated Water Resource Management (IWRM) emerged as the new paradigm. This is described by the Global Water Partnership [3] as the "process that promotes the coordinated development and management of water, land and related resources in order to maximize economic and social welfare in an equitable manner without compromising the sustainability of vital ecosystems". However, despite this focus on integration and the need to bridge different levels of decision making, considerable co-ordination and information sharing is required between multiple sectors and different layers of authority [4]. Many argue that it is too idealistic and unachievable in practice [5], having many disconnected principles [6] and inflexible governance to take uncertainty into account [7]. 
Actually, a large number of strategies and plans of action have been proposed by international agencies and communities to solve the water-related problems, such as the lack of safe drinking water for a significant part of the world's population, the insufficient amount of available water resources to achieve food security in several countries, and the growing risk for mankind due to water disasters, pollution, and the degradation of ecosystems [8]. However, improvement of the situation concerning these issues remains too slow according to the United Nations [8].

Applying these yet unresolved factors to Mexico and especially to the Yucatan Peninsula these water-related problems have worsened in the last decade, with water supplies dwindling and the demand for them increasing [9]. The data shows that the average water per capita supply in the country in the last 60 years has been reduced from 18,035 m³/person/year to $4090 \mathrm{~m}^{3} /$ person/year. The situation is now considered "critical" [10]. In the Yucatan Peninsula, from 1950 to 2010, the population increased from approximately 700,000 to over 4 million people, reducing the water per capita supply from almost $45,000 \mathrm{~m}^{3} /$ inhabitant /year to $7138 \mathrm{~m}^{3} /$ inhabitant/year. The water demand has subsequently increased from $3865 \mathrm{~m}^{3}$ /person/year in 2000 to $8800 \mathrm{~m}^{3} /$ person/year in 2010 [10].

But an increase in the population and economic growth do not always need to lead to a greater consumption of water. Between 1980 and 1995, the US population grew by 16\% but water consumption fell by $9 \%$ [11]. This decline is attributed to the more efficient use of water with policies being drafted to place a greater emphasis on the building of dams to store water.

Regarding the increase of populations, other problems have to be dealt with, such as "over-exploitation" of groundwater resources and "pollution" [12], which have to be coped with due to their serious environmental, social and economic impacts [13].

Especially, farmers of the Yucatan Peninsula (Figure 1) have to face other problems, such as poor soil and an inappropriate climate, which greatly limits the development of agriculture. The soil is stony and permeable, which does not allow the formation of surface run-off, preventing topographic changes and the use of agricultural machinery on the land. The average temperature is 26 degrees Celsius, with a seasonal rainfall around $900-1100 \mathrm{~mm} /$ year, which has meant relying on an erratic regime [9].

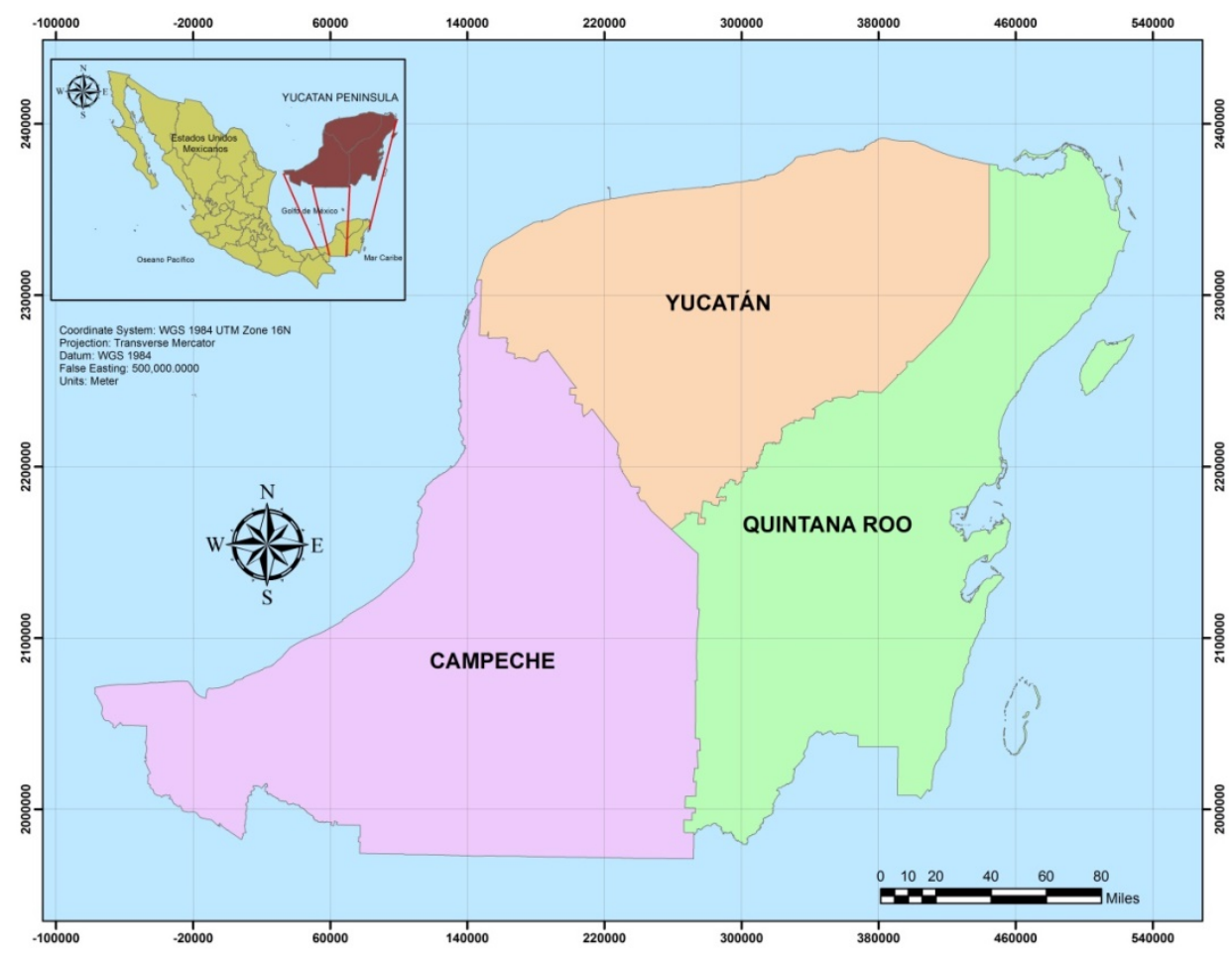

Figure 1. States belong to the Yucatan Peninsula. Source: [14]. 
Yet increasingly experts in water management are finding that rectifying engineering solutions for water management is insufficient [4]. This requires legal, institutional, technological and economic instruments as well as ethical principles which serve to guide human behavior [8]. Therefore, it is suggested that demand side management needs to be examined more closely, especially considering the ethical motivation of farmers [15].

In this regard, what kinds of actions are necessary to achieve a more responsible level of consumption? What are the factors that influence the use of water among farmers? How can the ethical sensitivity of farmers concerning water consumption be improved? This study makes a case for promoting a combination of a virtue and principle-based ethical approach to water management according to a sample of 123 producers scattered especially throughout localities from existing programmes in the irrigation district and other parts of the Yucatan Peninsula with irrigation units.

The aim of this methodology is to propose small farmer's best practices to be developed by water authorities through training and educational activities, inculcating the principles of participation, hydrosolidarity and proactive water-loss prevention in communities living in the Yucatan Peninsula so that better water management practices will be achieved there.

This hypothesis is tested by conducting an empirical investigation into the attitudes of farmers using a structured questionnaire. This questionnaire asks farmers what motivates their water management practices and analyses their answers statistically to establish what the biggest motivating factors are: principles, best practices, rules and price. We discuss the methodology proposed based on Partial Least Squares (PLS), following the use of PLS [16] according to structural equation modeling (SEM) that has been used for years in social sciences. This method allows the evaluation of the measurement and structural models taking into account not only the measurement error [17], moving towards the prediction of the dependent variable (the best practices) [18] as it relates to: principles, prices and state regulations. The article completes a review of the literature regarding water management. The review points to the growing importance of ethics in motivating for change in the practice of water consumers.

\section{Literature Review}

\subsection{Moving towards an Ethical Approach to Water Management}

The topic of water ethics is being increasingly discussed in policies and practices of water resource management [19]. Discussions concerning the importance of ethical discourses with regards to water management have also been growing and challenging the precepts of IWRM. With global water and food security increasing, water problems are becoming an issue of fundamental ethical values [20]. There have been many attempts to achieve an international agreement on water management goals, such as the UN Mar del Plata Conference in 1977, the Dublin Principles and in Rio de Janiero in 1992, the five World Water Forums of 1997, 2000, 2003 and 2006 and 2008 and the Millenium Development Goals of 2000 that aimed to reduce the population which cannot access safe drinking water by half by 2015 [21]. Nevertheless, it is understood that this kind of global action will not produce a change in behavior on the scale or with the continuity required to make a significant impact because the decisions which are made on the basis of broad agreements or basic compliance with regulations are unlikely to bring about "best practices", at best generating a minimum compliance [22,23].

In this regard, water resource management can be defined as the implementation of "best practices" for effective quantitative and qualitative planning, development, distribution and utilization of water. These management practices should ensure a long term, stable and flexible water supply capacity to meet multi-purpose water utilization, at the same time as maintaining a stable relationship between water using practices and their associated environmental consequences [24]. To develop "best practices", it is proposed that an environmental ethical awareness is required both globally and locally. To achieve this ethical discourse it is necessary to begin by enabling individuals and nations to move beyond individualistic behavior and legal compliance to an attitude of respect for the 
environment and the society at large [25]. This is not only a normative framework guiding actions that affect water [26] but, more concretely, it is understood as best management practices in natural resource policy providing an evaluating framework that prescribes correct behavior [27], describing the view that people have concerning ethical conduct [24], and providing us with a range of data to consider the world view of different people [24].

Ethics as a theoretical science is seen as a means of creating a practical motivation for changing behavior [28]. It is understood that this respectful awareness of the environment will allow people to develop values that make them model citizens who will proactively seek to protect water resources. The process of thinking via the ethical implications of alternative water policies and practices will favor outcomes that are better for us as people and for the planet on whose health we ultimately depend [19].

There are of course many ways in which this ethical discourse could be cultivated. The academic literature distinguishes between utilitarian, virtue-based and principled approaches to ethics [29]. Each of these approaches has its advantages, depending on the context being discussed.

The article supports a call for following a combined virtue/principle based approach where a long term attitude of respect is developed towards water. This attitude of respect is embodied by the cultivation of a few core principles made explicit by researching within the context of the Yucatan Peninsula what stakeholders believe are the core values needed to bring about best practices. It is envisaged that these principles would be inculcated within the community by becoming points of discussion in documents, community workshops and educational programmes and serve as guiding frameworks. These principles include: participation, solidarity and proactive water loss prevention.

Stakeholder participation is recognized as a key principle in Integrated Water Resource Management [30] and has become a key concept of water management in all modern international documents on water [31]. Stakeholder participation can be understood in two ways: upwards by providing citizens with "access to information" and downwards by giving them opportunities to "access participation" in decision-making processes related to water. Proposals about citizen participation focus on the responsibility of the various (public and private) bodies responsible for water management in each and every one of its phases (from planning and infrastructure design, to adjudication of rights and pricing; and secondly, the responsibility of individual citizens being involved in participation processes to discuss the water problems they face). Citizen participation is also considered one of the key criteria for establishing improved access to water by the World Health Organization [32].

Despite this emphasis on the principle of participation in the international literature and governance structures, citizen participation has declined in Mexico. This is believed to be largely due to the lack of career and training opportunities in the water sector. Moreover, the institutions created to co-ordinate this citizen participation have been monopolized by those established political and economic interests associated with the use and management of water.

The second two principles: solidarity and proactivity are essential components of the first principle. Solidarity looks more specifically at the participation of the poor and vulnerable who are often affected by the actions of farmers. Hydro-solidarity stresses the need to provide all individuals with access to drinking water and sanitation and to overcome the boundaries of river basins or administrative units to achieve this [21]. It seeks to bring ethical considerations such as equity into integrated water management that is often criticized for not paying sufficient attention to these issues. Hydrosolidarity can take many forms: interpersonal, international and intergenerational. International hydrosolidarity is expressed primarily through equity and the rational use of water masses and in the international co-operation with poor countries in the task of extending access to water, and sanitation for the poor. Education in solidarity refers to an "education in humanity". That is, to build a society which is truly human where people and their dignity remain at the center, and not the logic of profit (cf. Address by FAO, 20 June 2013 in their 38th conference). This principle is particularly important in facing the two main water problems in Mexico: the over-exploitation of groundwater resources by farmers and the pollution of wells. Farmers sink wells without permission, pollute the water and ignore the few 
regulations that are imposed by the government. They also illegally occupy public lands, creating interterritorial damage to other water users and the riverine eco-systems [12].

The third principle of proactive water loss prevention again relates to the issue of participation and the need for individuals and citizens to be involved in their own water management. This principle places the onus on communities to take preventative action and not to wait for government or rules to ensure water safety. It encourages communities to take it upon themselves to address infrastructure or leakage or pollution when needed [33]. The Mexican National Water Confederation (CONAGUA) has made this principle one of its focus areas with regards to water management. The aim is to "achieve a positive and proactive change in the way of participation in sustainable water use by producers and citizens, through a communication process to society and educational programmes at school, family and enterprises" [34]. It is focusing on spreading a new water culture in society by focusing on children and young people who are often more receptive to new ideas.

The application of this principle is thought to be able to prevent a lot of water loss and also reduce the costs of addressing long-term water management problems. This focus on promoting the proactive engagement of communities is well-supported in the literature on water management with some authors suggesting that proactive action is necessary in order to mitigate the over-use of groundwater [20]. In fact, water quality has deteriorated over the past few years due to the untreated residual water that runs into the river and also contaminates groundwater [12], creating harmful water crises within communities. It is not enough to have regulations to control this problem [35].

\subsection{Initiatives Aimed at Developing a New Water Culture in Mexico}

The Mexican government has launched several technical and administrative policy initiatives to focus on the severe water stress that the country is experiencing. The ambitious 2030 Water Agenda was launched in 2011 to achieve "clean water bodies, balance supply and demand, universal coverage and settlements safe from catastrophic floods". This policy framework is supported by law (National Water Law), by updated plans [12] and institutions at multiple levels (i.e., the National Water Commission and River Basin Councils) to ensure its implementation. However, despite all these efforts, implementation has not been as successful as expected (Organization for Economic Cooperation and Development-OECD) [36] with a number of gaps being noted in a report on water reform in Mexico by the OECD. Among other issues, the report discusses the need for better policy coherence with regards to water and energy, the need to make water policy more cost efficient and address gaps in legislation. While mention is made of the need to improve public participation, nothing is said about the need to develop a new water ethic.

Nonetheless, this issue appears in the Mexican National Water Plan 2014-2018 [12] that seeks to develop a new "water culture" and build "an informed and participative society". It highlights the fact that the true economic, social, and environmental value of water is being ignored in Mexico, leading to its inefficient use, wastage, overexploitation and degradation. . It calls for a water reform process that does not only look at the purely technical hydrological needs of water resources management but also considers the deeper important social and environmental concerns.

Exactly how this could be achieved is not, however, clear in the National Water Plan or other supporting documents. According to the amendment of Article 4 of the Constitution of the United Mexican States, everyone has the right to access water and sanitation provision for personal and domestic consumption [37].

Notwithstanding, it is also generally understood that what is free is not sufficiently valued and that water resources are often polluted by users. The National Water Plan notes that water pollution in Mexico is largely due to the contamination of untreated wastewater by municipalities and industries, the use of fertilizers and pesticides in agriculture, inadequate collection and disposal of solid municipal and industrial waste and the accelerated process of erosion caused by inadequate agricultural and forestry activities [12]. 
In Mexico in 2011, the volume of residual water from urban areas was about 7.5 cubic kilometers (equivalent to about $236.3 \mathrm{~m}^{3} / \mathrm{s}$ ) [38]. This volume grew alongside the increase in population and urbanization: between 2000 and 2005, the generation of waste water from urban centers increased about $7 \%$ (equivalent to $16 \mathrm{~m}^{3} / \mathrm{s}$ ), but from then onwards, until 2010, there was a decrease in the volume of discharged flow. However, the increase was experienced again in 2011. The National Water Commission recently found that $40 \%$ of aquifers suffer some degradation caused by anthropogenic activities and natural causes [12].

The overexploitation of groundwater is another problem. This has deteriorated the water quality over the past few years due to the untreated residual water that runs into the river and has also contaminated groundwater [12], creating harmful water crises within communities. Moreover, out of the 653 aquifers identified by the CONAGUA, 32 of them were already overexploited in 1975 and a further 104, more than triple that, in 2004. This overexploitation is largely due to the uneven distribution of the population in the country. A total of $77 \%$ of the population lives in the central and northern areas of the country where only $32 \%$ of the water is located. To reverse this trend, the National Water Law (LAN) established control mechanisms by installing water in the country's agricultural wells. Meanwhile, CONAGUA coordinates programmes for the Efficient Use of Water and Electricity and Full Use Infrastructure Hydro-agricultural, with the support of which it provides users of irrigation units the chance to increase the efficiencies of their equipment pumping, and modernize their farms and introduce technology in order to achieve a better use of water and increase agricultural productivity [9]. Yet with all these efforts, the overexploitation of aquifers continues, as does the growing social conflict associated with it. Moreover, a poor culture of payment for using water and the sanitation services prevails [12]. For the purpose of a sustainable and rational utilization of scarce water resources and to encourage environmentally friendly attitudes, the relevant authorities must carry out incentive measures, including an appropriate water pricing policy. Through setting the price, operational costs for the water service and the resource costs may both be recovered [24].

Mexico, like many other developing countries, has to be careful about how it prices water. On average, citizens in developing countries have to pay a higher percentage of their income on water (between $5 \%$ and $10 \%$ ) whereas in developed countries this is much less (between $1 \%$ and $3 \%$ ) [39]. However, while the Mexican government has a duty to provide water to everyone, especially poor people, it also has to cover the infrastructure costs of ensuring the supply. This is specifically important in agriculture in Mexico because the trend has been to subsidize the water supply in this sector and not cover the minimal cost, resulting in high levels of waste and inefficiency among farmers [40].

Globally, the ethical challenge with regards to supplying water is thus complex. There is a triple moral imperative: to facilitate access to water to those who lack a sufficient income to pay the real costs of this service, to ensure an adequate payment for services of those who can, so as to cover infrastructure and maintenance costs, and lastly to encourage a moderate consumption of all those with access to water [41]. This article argues that for this tricky balance in policy to be preserved, it needs to be supported by a deeper ethical awareness about the value of water as a vital life source that needs to be sensitively used and paid for. The question thus arises as to how a new water ethic could be introduced and maintained by the majority of users.

\section{Case Study}

\subsection{Objective of the Research}

A critical discourse related to the way of attaining motivation for ethical behavior towards water has arisen. The approach used to determine attitudes and motivations appears to be questioned - either its internal aspects (principles) or external issues (government rules, price). Moreover, "principles" can give an intrinsic value to subjects, or to their behavior [15] through an ethical application to water or "values" [19], such as personal or cultural standards [19]. Therefore, principles, such as 
participatory and values-based action may yield appropriate insights and provide reliable information for developing farmer's ethical water attitudes.

Ethics and values are, then, used interchangeably, although with certain distinctions [19]. While "values" refers to criteria to guide not only the action but also the attitude or judgment [19], "ethics" refers to a coherent system of values [19]. Both are presumably required to develop people's internal motivations.

More explicitly, the sub-commission of the World Commission on the Ethics of Science and Technology (COMEST) argued that, rather than analyzing once more the ethical issues of water management, it should try to promote best ethical practices through some fundamental principles: Participation, Solidarity, etc. [24].

Our argument is to know if best practices can be undertaken through internal or external aspects. Initially, there is a need to develop an identification with the overall good of human beings to inspire better practices, but this could also be tackled by external aspects based on self- or normative interest to comply with this. Both internal and external aspects are well supported by the literature as attitudes which need to be developed and which require a focus on creating virtuous actions [28,42].

The development of virtues is effective in developing best practices because doing so creates the necessary components of people: intellectual, emotional-[29]—both of which are required to ensure best practices, to be developed by water authorities through training and educational activities. This is why continuing education and voluntary actions remain important parts of any ethical strategy. Through continual training and making efforts to collaborate with others improved water management is most likely in any community [43].

\subsection{Methodology}

In order to test our hypothesis that inculcating an attitude of respect for water (embodied by core principles that have been identified by stakeholders) plays a significant role in the development of best practices among small farmers in the Yucatan Peninsula, Mexico, we drew up a questionnaire and asked the farmers themselves what was motivating them towards best practices with regards to water management. For the selection of the study variables, we conducted preparatory interviews between 10 January and 24 February 2015 with key stakeholders including farmers, national and regional public officials from the National Water Commission.

The criteria that we have established are based on a division of localities from existing programmes in the irrigation district and other parts of the Yucatan Peninsula. The distribution of questionnaires was carried out in temporary irrigation districts by the technicians of CONAGUA in 2015.

It is estimated that there are 6500 small farmers in the Yucatan Peninsula. However, every year, some farmers are enlisted in the irrigations systems programmes of the Yucatan Peninsula, though a high percentage of them give up the hydrological programmes a few months later, without communicating anything to the water authorities. The water authority has estimated that no more than 600 small farmers are actually enrolled in the water programmes.

Since there is no updated official list of farmers enrolled in the CONAGUA programme, the water authority selected as a criteria for this research those farmers who had participated in CONAGUA's activities during 2015. There were almost 230. A communication was sent from that institution to all of them asking if they were willing to be involved in the research. Approximately $54 \%$ replied. Finally, 123 producers were involved, scattered throughout the state. The distribution of producers is spread over locations whose frequency is presented in Figure 2 below.

The producer's responses are organized in four constructs: "best practices", "principles", "rules" and "price" (Figure 3). We called the first construct "best practices". The indicators for this construct were derived from the working meetings held with experts and directors of each of the sections of the CONAGUA concerned with water management among small farmers. They identified three main issues within water management in the area: pollution, wasteful behavior, and lack of access to water. They also identified four indicators of best practices, which were: "Report cases of unethical behavior 
with water" (BP1), "Stop wasteful behavior" (BP2), “Develop a water-saving mentality" (BP3), “Do not pollute the water in the area" (BP4).

CAMPECHE

YUCATÁN

QUINTANA ROO

IRRIGATION DISTRICTS

TECHNIC TEMPORAL DISTRICTS

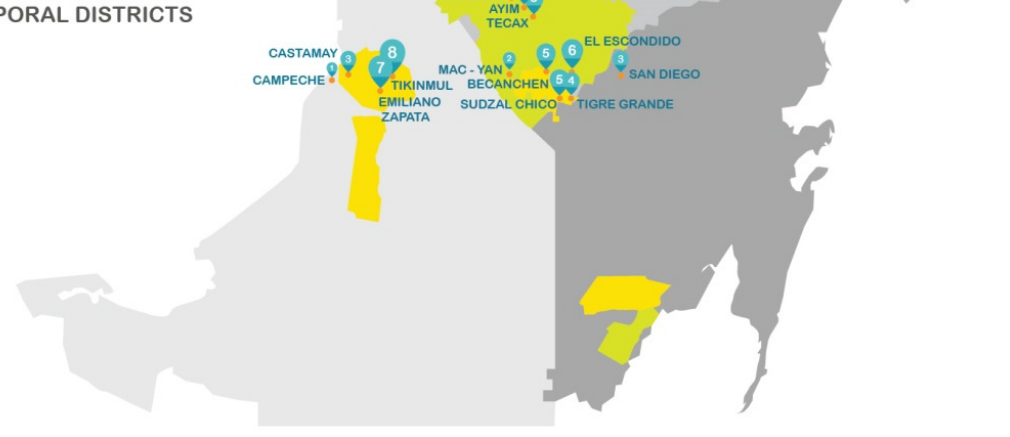

Figure 2. Distribution of producers in the Yucatan Peninsula. Source: Authors.

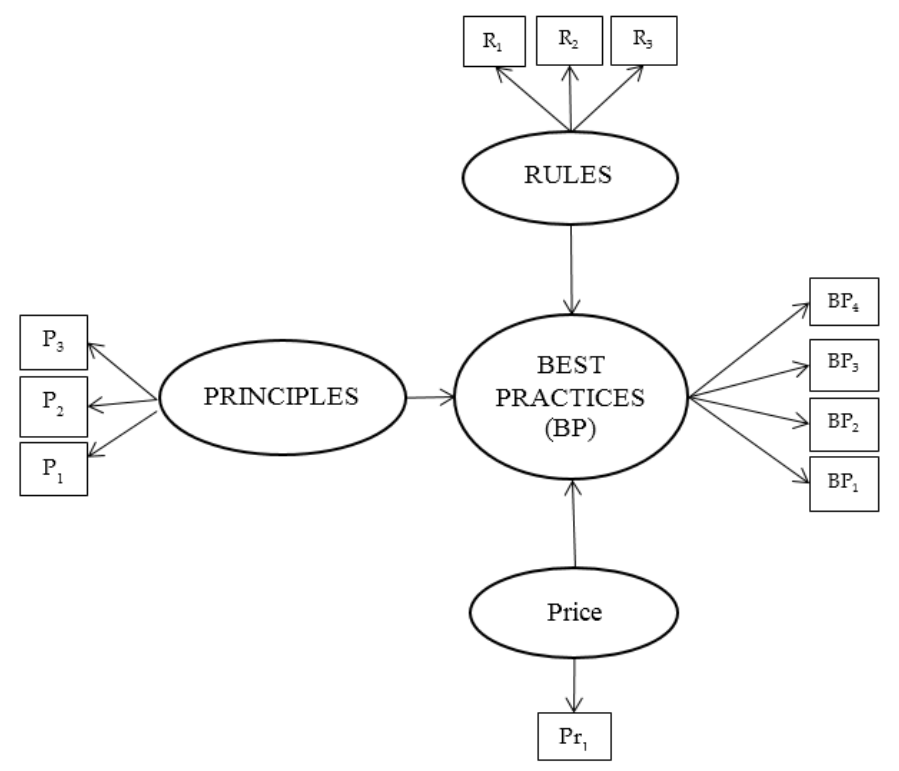

Figure 3. Hypothesized model for Best Practices. Source: Authors.

The second construct was labelled "principles". Based on the literature, we focused on three principles directly related to the ethical use of water: (P1) "Participation" [31,44,45], (P2) "Solidarity" [20], and (P3) "Proactive" water loss prevention [32]. We were interested in knowing how these principles influenced the development of best practices. In order to ensure that small farmers would recognize how the applications of these principles might affect their behavior with regards to water consumption, CONAGUA's irrigation units organized meetings with the participants of the study before they answered the questionnaire. These meetings not only helped ensure that the farmers understood the questionnaire correctly but also allowed the government officials to design improved training campaigns for decision makers, farmers, schools and the general population.

The third construct was labelled "rules". The enforcement of rules or regulations provides some general guidelines for farmers to follow to ensure a better use of water. We were interested in finding out what aspects of the enforcement of legislation were helpful in preventing the misuse of water. 
Following meetings with officials, the following enforced regulations were tested: (R1) "The removal of illegal taps", (R2) "The installation of meters" to record water use by individual farmers and (R3) "The penalization of excessive water consumption".

The fourth construct, price (Pr1), needs little explanation. We were interested in assessing how an increase in the price of water affected the behavior of farmers with regards to water use. Did the higher cost of water lead to a higher regard for its value and its better management by farmers?

Table 1 shows the descriptive statistics of the indicators grouped into the constructs considered. Each construct allows us to analyze not only the degree of importance of the variable within each construct, but also the relationship between the two constructs.

Table 1. Descriptive Statistics of indicators grouped into constructs.

\begin{tabular}{|c|c|c|c|c|c|c|}
\hline Best Practices & & Mean & Min & Max & Mode & Stand. Dev. \\
\hline & Report cases of unethical behavior on water & 7.146 & 0 & 10 & 10 & 3.552 \\
\hline & Stop wasteful behavior & 6.049 & 0 & 10 & 1 & 3.767 \\
\hline & Develop a water-saving mentality & 5.138 & 0 & 10 & 10 & 3.922 \\
\hline & Do not pollute the water in the area & 6.862 & 0 & 10 & 10 & 3.653 \\
\hline \multicolumn{7}{|l|}{ Principles } \\
\hline & Participation & 5.618 & 0 & 10 & 10 & 3.908 \\
\hline & Solidarity & 5.943 & 0 & 10 & 0 & 3.969 \\
\hline & Proactive & 6.146 & 0 & 10 & 0 & 3.931 \\
\hline \multicolumn{7}{|l|}{ Rules } \\
\hline & Control of illegal taps & 4.390 & 0 & 10 & 1 & 4.246 \\
\hline & Install meters & 4.439 & 0 & 10 & 1 & 4.117 \\
\hline & Penalize excessive water consumption & 3.919 & 0 & 10 & 0 & 3.935 \\
\hline \multicolumn{7}{|l|}{ Price } \\
\hline & Increase the price & 3.179 & 0 & 10 & 1 & 3.617 \\
\hline
\end{tabular}

\subsection{Selected Statistical Technique}

An epistemic relationship, or measurement model, describes the link between theory (constructs) and data (indicators), or the relationships between measures and first-order latent constructs. There are two basic types of epistemic relationships [46].

On the one hand, the reflective measurement model posits that the covariation among measures is explained by the variation in an underlying common latent factor. In this case, indicators are reflective of the unobserved theoretical construct, hence they co-vary with the level of that latent variable. On the other hand, the formative measurement model establishes that the measures jointly influence the composite latent construct. Manifest variables, called formative indicators, give rise to the latent variable, so they produce or contribute to the construct.

The primary difference between reflective and formative measurement is that while the construct causes variance in its reflective indicators, the direction of causality is reversed in such a way that the formative indicators cause variance in the construct. Reflective measures are by far the most common type of measurement used in SEM. The indicators of our constructs (BP1, BP2, BP3 and BP4 for Best Practices; P1, P2 and P3 for Principles; R1, R2 and R3 for Rules and Pr1 for Price) are obtained by a questionnaire. In this sense, they are indicators of the latent phenomena and they cannot be the cause of the phenomena [47]. Following the four criteria suggested by [46], we have determined that all our constructs are reflective.

The research model described in Figure 3 has been assessed using partial least squares (PLS) path modeling, an approach to structural equation modeling (SEM) that has been used for many years in social sciences, and has recently commanded considerable attention in several business disciplines, such as marketing [48] and operation management [49], among others.

The holistic analysis that SEM is capable of performing can be carried out via one of two distinct statistical techniques: on the one hand, covariance-based SEM (CBSEM), as represented by software 
such as LISREL, EQS and AMOS; on the other hand, variance-based (or components-based) SEM, i.e., partial least squares [18].

Although CBSEM has until recently been the most well-known SEM approach, PLS has also been gaining an increase in the interest of social science researchers. In a single, systematic, and comprehensive analysis, PLS allows evaluating measurement and structural models, taking measurement error into account [17].

In this contribution, we have chosen the PLS technique over CBSEM for the following reasons: (1) this study is oriented towards the prediction of the dependent variable [18]; (2) the research model is complex [49] both in the number of variables (manifest and latent) and relationships postulated. We have specifically used SmartPLS [50].

With regards to multiple linear regression (MLR) analysis, Partial Least Squares (PLS) enables the overcoming of the following limitations [51]: (a) the postulation of a simple model structure; (b) the assumption that all variables can be considered as observable; and (c) the conjecture that all variables are measured without error. In addition, [52] indicate that PLS offers a number of additional advantages over MLR.

In particular, PLS does not require: (1) normality of data distributions; (2) observation independence; and (3) variable metric uniformity. Besides, PLS enables a greater consistency between the meaning of measurement items and their definition in a research model. That is, PLS can integrate both reflective and formative measurement models, as is the case in this study. Finally, [52] show that the regression coefficients provided by PLS are more likely to be closer to the true values than with MLR.

\section{Results}

It is suggested by [53] that there are two stages in the PLS analysis: firstly, the assessment of the measurement model, and secondly the analysis of the structural model. This succession permits the availability of appropriate indicators of constructs before attempting to reach conclusions concerning the relationships included in the structural model [48].

\subsection{Measurement Model}

The evaluation of the measurement model seeks to analyze whether the theoretical constructs are correctly gauged by the measures (Table 2).

Table 2. Assessment of the measurement model.

\begin{tabular}{|c|c|c|c|}
\hline & \multirow[t]{2}{*}{ Loading } & \multicolumn{2}{|c|}{ Confidence Interval } \\
\hline & & Upper & Lower \\
\hline \multicolumn{4}{|l|}{ Best Practices } \\
\hline Report cases of unethical behavior on water & 0.911 & 0.949835 & 0.860435 \\
\hline Stop wasteful behavior & 0.862 & 0.9179 & 0.71914 \\
\hline Develop a water-saving mentality & 0.875 & 0.917345 & 0.79898 \\
\hline Do not pollute the water in the area & 0.733 & 0.81981 & 0.561155 \\
\hline \multicolumn{4}{|l|}{ Principles } \\
\hline Participation & 0.877 & 0.92717 & 0.806975 \\
\hline Solidarity & 0.773 & 0.86471 & 0.64132 \\
\hline Proactive & 0.899 & 0.941265 & 0.831845 \\
\hline \multicolumn{4}{|l|}{ Price } \\
\hline Increase the Price & 1.000 & 1.000 & 1.000 \\
\hline \multicolumn{4}{|l|}{ Rules } \\
\hline Control of illegal taps & 0.901 & 0.90979 & 0.795355 \\
\hline Install meters & 0.889 & 0.903285 & 0.745425 \\
\hline Penalize excessive water consumption, & 0.912 & 0.91856 & 0.81708 \\
\hline
\end{tabular}

Source: Authors. 


\subsection{Evaluation of Reflective Measurement Models}

The measurement model for reflective constructs is assessed in terms of individual item reliability, construct reliability, convergent validity, and discriminant validity (Appendix). Individual item reliability is assessed by analyzing the standardized loadings $(\lambda)$. Usually, it is required that the indicators surpass a minimum level of 0.707 defined by [54]. Our study presents this scenario (Table 3).

Table 3. Construct reliability, convergent and discriminant validity coefficients.

\begin{tabular}{lcccccc}
\hline & AVE & Composite Reliability & (1) & (2) & (3) & (4) \\
\hline (1) Best practices & 0.719 & 0.910 & 0.8479 & & & \\
(2) Rules & 0.812 & 0.928 & 0.5561 & 0.901 & & \\
(3)Principles & 0.724 & 0.887 & 0.6410 & 0.5913 & 0.8508 & \\
(4) Price & 1 & 1 & 0.3666 & 0.6601 & 0.4023 & 1 \\
\hline
\end{tabular}

Source: Authors.

With regards to the construct reliability, all constructs achieve values for the composite reliability index [54] greater than 0.7, required in early stages of research [55]. Convergent validity is assessed via the average variance extracted (AVE) [56]. AVE values should be greater than 0.50 [17]. Consistent with this suggestion, AVE measures for all variables exceed 0.663 (Table 3).

For discriminant validity, we compare the square root of the AVE with the correlations between constructs (i.e., the off-diagonal elements in Table 3). In order to meet the discriminant validity requirement, the diagonal elements should be significantly greater than the off-diagonal elements in the corresponding rows and columns [18].

This condition is satisfied. Consequently, each construct relates more strongly to its own measures than to others.

\subsection{Structural Model}

The assessment of the structural model is based on the algebraic sign, magnitude and significance of the structural path coefficients, the $\mathrm{R}^{2}$ values, and the $\mathrm{Q}^{2}$ (redundancy) test for predictive relevance. With the aim of assessing the statistical significance of the path coefficients, we applied a bootstrapping process (5000 resamples) to generate standard errors and $t$-statistics [48].

We additionally report the bootstrapping confidence interval of standardized regression coefficients. "If a confidence interval for an estimated path coefficient w does not include zero, the hypothesis that w equals zero is rejected" [16].

Specifically, we have applied a percentile approach, which has the advantage of being completely distribution free [18]. Among the direct effects hypothesized in Figure 3, Price is not significant. The other constructs, Rules and Principles, are strongly significant. This conclusion is also consistently achieved analyzing the percentile bootstrap 95\% confidence intervals (Table 4).

Table 4. Significance of the path coefficients.

\begin{tabular}{|c|c|c|c|c|c|c|}
\hline & $\mathbf{R}^{2}$ & $\mathrm{Q}^{2}$ & Direct Effect & $t$-Value & $\begin{array}{c}\text { Confidence } \\
\text { Interval }\end{array}$ & $\begin{array}{l}\text { Variance } \\
\text { Explained }\end{array}$ \\
\hline (1) Best Practices & $45.90 \%$ & 0.32 & & & & \\
\hline (2) Price & & & -0.011 & 0.117 & {$[0.1515 ;-0.1481]$} & $0 \%$ \\
\hline (3) Rules & & & 0.279 & 3.394 & {$[0.41066 ; 0.1381]$} & $15 \%$ \\
\hline (4) Principles & & & 0.480 & 6.032 & {$[0.6421 ; 0.3633]$} & $31 \%$ \\
\hline
\end{tabular}

The coefficients estimates specify the relationship between unobservable factors hypothesized to determine Best Practices. In general, the sign of the relationship between hypothesized determinants 
and Best Practices measures is consistent with the theory. The measures have a positive sign. In our starting hypothesis these constructs could assume a positive sign.

The dependent variable achieves an $R^{2}$ value of 0.459 (Table 4 ). This is above the moderate level proposed by [53]. A "good" level of $R^{2}$ does not exist, but it is generally accepted that values above 0.30 are considered meaningful. We also evaluate the model with the cross-validated redundancy index $\left(\mathrm{Q}^{2}\right)$ for the endogenous construct. In [53], it suggests this measure to examine the predictive relevance of the theoretical/structural model. $\mathrm{A}^{2}$ greater than 0 implies that the model has predictive relevance. Table 4 confirms that the structural model has satisfactory predictive relevance for the Best Practices variable $\left(Q^{2}=0.32\right)$. Finally, Table 5 also shows the amount of variance that each antecedent variable explains of the Best Practices. The construct Price explains $0 \%$ of the variance, the construct Rules $15 \%$ and the construct Principles $31 \%$. It is worth mentioning that the sum of the explained variances cannot exceed the $\mathrm{R}^{2}$, that is the total variance explained by the model.

\section{Discussion}

By using a sample of farmers scattered especially throughout localities from existing programmes in the irrigation district and irrigation units of the Yucatan Peninsula and applying the PLS statistical technique to a questionnaire where we ask farmers what motivates them towards best practices, we are able to demonstrate the importance of developing a virtue-based approach to water management. The results show that the ethical principles discussed are by far the highest driver towards best practices among small farmers in the Yucatan Peninsula, followed by regulations enforcing best practices and then price. This sample supports the academic literature's emphasis on the need to include ethical principles in water management. It also supports our hypothesis that ethics is a major motivating factor towards achieving best practices. Within the context of the Yucatan Peninsula, it could be argued that inculcating a respectful attitude to water use would be the most effective measure to use at this point in time, far more effective than increased regulation or price. It is not the subject matter of this research to look at how this could be achieved but obvious examples would be through encouraging the internalization of the three principles through community, school and tertiary forms of education and awareness raising.

Nevertheless, it is true that one cannot assume that the same principles-increased participation, solidarity and the nurturing of a proactive approach to water management-would develop a more respectful attitude to water use in every context. Nor can one assume that an ethical approach to water management, rather than regulation and price would always be the best means to address water issues. This would have to be tested and researched within each context. What this research does indicate conclusively, however, is that one cannot continue to ignore ethics as a consideration when looking at ways of improving water management.

One of the main contributions of this research is the methodology that has been tested. The PLS statistical technique when combined with a locally-developed structured questionnaire that probes for virtues, price and regulations provides a reliable and easy method to ascertain how to achieve best practices in any context. We have applied this methodology in the Yucatan Peninsula in Mexico but a very similar questionnaire could be constructed that also questions the impact of price, ethics and regulations among farmers elsewhere in the world. This methodology would be especially useful for governments to guide their conduct with regards to improved water management.

Acknowledgments: All the research behind the article it have only possible thanks to the collaboration of the European Project (IRSES-GA-2013-612686-ECODRY) and the National Water Institute (CONAGUA). The grant that it has received in support of the research work has been $(7590,34 €)$. We do not have received any funds for covering the cost to publish in open access.

Author Contributions: Rafael Robina has coordinated the article, designed the experiments, also has maintained the research relations with the National Water Institute (CONAGUA) supervising all the steps to finalize the article Leanne Seeliger contributed to the literature review and philosophical analysis of the ethical arguments for improved water management; Filippo Di Pietro has coordinated the methodology of the article througt Partial Least Square (PLS). 
Conflicts of Interest: The authors declare no conflicts of interest.

\section{Appendix}

Reliability

Reliability is tested by checking that, for each construct: [57] $\alpha$ is higher than the recommended value of 0.70 [58]. Being

$$
\alpha=\frac{\mathrm{k} \rho}{1+(\mathrm{k}-1) \rho}
$$

where $k$ is the number of indicators of the construct and $\rho$ the average correlation between those indicators.

Composite Reliability

According to [56], Composite reliability [59] should also be higher than 0.70. Its formula is:

$$
\mathrm{CR}=\frac{\left(\sum_{\mathrm{j}} \lambda_{\mathrm{ij}}\right)^{2}}{\left(\sum_{\mathrm{j}} \lambda_{\mathrm{ij}}\right)^{2}+\sum_{\mathrm{j}} \operatorname{Var}\left(\varepsilon_{\mathrm{ij}}\right)}
$$

Being $\Lambda$ the loading estimation of the $\mathrm{j}$ indicator of the $i$ th construct. $\operatorname{Var}\left(\varepsilon_{i j}\right)$ is related to the loadings as follows:

$$
\operatorname{Var}\left(\varepsilon_{\mathrm{ij}}\right)=1-\lambda^{2}
$$

\section{Convergent Validity}

According to [56], the variance that a construct explains of its indicators should be higher than the variance due to measurement error. An average variance extracted index (AVE) higher than 0.50 assures this requirement.

$$
\operatorname{AVE}_{\mathrm{i}}=\frac{\sum_{\mathrm{j}} \lambda_{\mathrm{ij}}}{\left(\sum_{\mathrm{j}} \lambda_{\mathrm{ij}}\right)^{2}+\sum_{\mathrm{j}} \operatorname{Var}\left(\varepsilon_{\mathrm{ij}}\right)}
$$

All the notations are equivalent to the composite reliability formula

\section{Predictive Relevance}

According to $[56,60]$ test criterion, $Q^{2}$ statistic $[60,61]$ evaluates how well the observed values can be reconstructed by the model and its parameters. $Q^{2}$ is estimated by the following formula:

$$
\mathrm{Q}^{2}=1-\frac{\mathrm{E}}{\mathrm{O}}
$$

where $\mathrm{E}$ is the sum of the squares of predictions errors and $\mathrm{O}$ is the sum of the square of the errors from the trivial prediction given by the mean of the remaining data points.

\section{Significance of the Estimation}

Partial least squares path modeling (PLS) unlike traditional ordinary least squares (OLS) estimation does not make assumptions about the distribution of the indicators. For this reason, when the algorithm performs the OLS estimation of the path coefficients, $t$ values from the OLS estimation cannot be used, as that would force the assumption of the multivariate normal distribution of the data.

Bootstrapping is the alternative PLS uses to calculate the significance of the model's two regression coefficients. The algorithm extracts $\mathrm{N}$ random subsamples from the original data. The size of any of these subsamples must be the same as the original data sample size, which imposes a sampling with a 
replacement procedure. The PLS model is estimated for each of those $\mathrm{N}$ subsamples, providing us with $\mathrm{N}$ estimations of each parameter (path coefficients, loadings and weights). Accordingly, the mean of the estimations of each parameter can be computed as well as their standard errors. The bootstrapped $t$-statistic used to test the null hypothesis that the parameters equal 0 can be computed as [53]:

$$
\mathrm{t}-\text { statistic }=\frac{\beta}{\operatorname{se}(\beta)}
$$

where the $t$-statistic follows a Student's $t$ distribution with $N-1$ degrees of freedom, $\beta$ is the original estimation of the path coefficient and $\operatorname{se}(\beta)$ is the bootstrapping standard error of that parameter estimation.

\section{References}

1. Gupta, J.; Pahl-Wostl, C.; Zondervan, R. "Glocal" water governance: A multi-level challenge in the anthropocene. Curr. Opin. Environ. 2013, 5, 573-580. [CrossRef]

2. Pahl-Wostl, C.; Jeffrey, P.; Isendahl, N.; Brugnach, M. Maturing the new water management paradigm: Progressing from aspiration to practice. Water Resour. Manag. 2011, 25, 837-856. [CrossRef]

3. Global Water Partnership. Available online: http://www.gwp.org/en/The-Challenge/What-is-IWRM/ (accessed on 21 September 2015).

4. Martinez-Santos, P., Aldaya, M.M., Llamas, M.R., Eds.; Integrated Water Resources Management in the 21st Century: Revisiting the Paradigm; CRC Press: Boca Raton, FL, USA, 2014.

5. Medema, W.; McIntosh, B.S.; Jeffrey, P.J. From premise to practice: A critical assessment of integrated water resources management and adaptive management approaches in the water sector. Ecol. Soc. 2008, 13, Article 29.

6. Van Koppen, B.; Schreiner, B. Moving beyond integrated water resource management: Developmental water management in South Africa. Int. J. Water Resour. Dev. 2014, 30, 543-558. [CrossRef]

7. Muller, M. The "Nexus" as a Step Back towards a More Coherent Water Resource Management Paradigm. Water Altern. 2015, 8, 675-694.

8. Rossi, G. Achieving Ethical Responsibilities in Water Management: A Challenge. Agric. Water Manag. 2015, 147, 96-102. [CrossRef]

9. CONAGUA. Programa de medidas preventivas y de mitigación de la sequía. Consejo de Cuenca Península de Yucatán, 1st ed.; Secretaría de Medio Ambiente y Recursos Naturales: Mérida, México, 2014. (In Spanish)

10. INEGI. Censo de Población y Vivienda 2010: Quintana Roo; Mexico, 2010. Available online: www.inegi.gob.mx (accessed on 19 August 2015). (In Spanish).

11. Hutson, S.S. Estimated Use of Water in the United States in 2000; Geological Survey (USGS): Virginia, VA, USA, 2004.

12. Mexican National Water Plan. (2014). Available online: http://www.conagua.gob.mx/CONAGUA07/Contenido/ Documentos/PROGRAMA_Nacional_Hidrico_2014_2018_ingles.pdf (accessed on 9 December 2015).

13. Di Stefano, L.; Lopez-Gunn, E. Unauthorized groundwater use: Institutional, social and ethical considerations. Water Policy 2012, 14, 147-160.

14. CONAGUA. Mérida (Yucatan Peninsula); CONAGUA: Mérida, Mexican, 2016.

15. Groenfeldt, D.; Schmidt, J.J. Ethics and water governance. Ecol. Soc. 2013, 18, Article 14. [CrossRef]

16. Henseler, J.; Ringle, C.M.; Sinkovics, R.R. The use of partial least squares path modeling in international marketing. Adv. Int. Mark. 2009, 20, 277-320.

17. Roldán, J.L.; Sánchez-Franco, M.J. Variance-Based Structural Equation Modeling: Guidelines for Using Partial Least Squares. In Information Systems Research, in Research Methodologies, Innovations and Philosophies in Software Systems Engineering and Information Systems; Mora, M., Gelman, O., Steenkamp, A., Raisinghani, M., Eds.; Information Science Reference: Hershey, PA, USA, 2012; pp. 193-221.

18. Chin, W.W. How to write up and report PLS analyses. In Handbook of Partial Least Squares: Concepts, Methods and Applications; Esposito Vinzi, W., Chin, W., Henseler, J., Wang, H., Eds.; Springer-Verlag: Berlin, Germany, 2010; pp. 655-690. 
19. Ziegle, R. Review of David Groenfeldt, Water Ethics-A Values Approach to Solving the Water Crisis. Environ. Values 2015, 24, 431-433. [CrossRef]

20. Lopez-Gunn, E.; De Stefano, L.; Llamas, M.R. The role of ethics in water and food security: Balancing utilitarian and intangible values. Water Policy 2012, 14, 89-105. [CrossRef]

21. Rossi, G. Ethical Perspectives for Sustainable and Equitable Water Management; Università Iuav di Venezia: Tolentini, Italy, 2011.

22. Melé, D. Ethical Education in Accounting: Integrating Rules, Values and Virtues. J. Bus. Ethics 2005, 57, 97-109. [CrossRef]

23. Fernández Fernández, J.L. Las Modalidades del Razonamiento y la Argumentación Ética. In La ética Empresarial y la Responsabilidad Social en el Nuevo Contexto Digital; Bajo Sanjuán, A., Villagra García, N., Eds.; Universidad Pontificia Comillas de Madrid: Madrid, Spain, 2010. (In Spanish)

24. United Nations Educational, Scientific and Cultural Organization (UNESCO). UNESCO Bangkok Regional Unit for Social and Human Sciences in Asia and the Pacific; Water Ethics and Water Resource Management. Ethics and Climate Change in Asia and the Pacific (ECCAP) Project Working Group 14 Report; UNESCO: Paris, France, 2011.

25. Giordano, M.; Villholth, K.G. The Agricultural Groundwater Revolution: Opportunities and Threats to Development; CAB International: Oxfordshire, UK, 2007; pp. 100-130.

26. Schmidt, J.J. Water ethics and water management. In Water Ethics: Foundational Readings for Students and Professionals; Brown, P.G., Schmidt, J.J., Eds.; Island Press: Washington, DC, USA, 2010.

27. Brown, P.G.; Schmidt, J.J. Water Ethics; Island Press: Washington, DC, USA, 2010.

28. Rodríguez Luño, A. Ética General; EUNSA: Pamplona, Spain, 2004.

29. Rachels, J.; Rachels, S. The Elements of Philosophy; McGraw-Hill: New York, NY, USA, 2007.

30. Benson, D.; Gain, A.K.; Rouillard, J.J. Water governance in a comparative perspective: From IWRM to a "nexus" approach. Water Altern. 2015, 8, 756-773.

31. Khalfan, A.; Roaf, V.; Grimes, H.; Langford, M.; Fairstein, C.; Russell, A.; Kiefer, T. Manual on the Right to Water and Sanitation; COHRE, AAAS, SDC and UN-HABITAT: Geneva, Switzerland, 2007.

32. Howard, G.; Bartram, J. Domestic Water Quantity, Service Level, and Health; World Health Organization: Geneva, Switzerland, 2003.

33. Park, H.J. A Study to Develop Strategies for Proactive Water-Loss Management. Available online: http://scholarworks.gsu.edu/pmap_diss/13 (accessed on 20 August 2015).

34. Perevochtchikova, M. Nueva cultura del agua en México: Avances, limitaciones y retos. Rev. Latinoam. Recur. Nat. 2010, 6, 77-92. (In Spanish)

35. Aguilar Ibarra, A.; Pérez, Espejo. La contaminación agrícola del agua en México: retos y perspectivas. Problemas del Desarrollo. Rev. Latinoam. Econ. 2008, 39, 205-215. (In Spanish)

36. Organisation for Economic Cooperation and Development (OECD). Making Water Reform Happen in Mexico. 2013. Available online: http://www.oecd.org/gov/regional-policy/makingwaterreformhappen inmexico.htm (accessed on 13 April 2016).

37. Mexico Constitución Políticia de los Estados Unidos Mexicanos. Diario Oficial de la Federación. 5 de Febrero de 1917. Available online: http:/ / www.diputados.gob.mx/LeyesBiblio/htm/1.htm (accessed on 15 March 2016). (In Spanish).

38. SEMARNAT. Informe de la situación del medio ambiente en México. Compendio de Estadísticas Ambientales Indicadores Clave y de Desempeño Ambiental; Secretaria de Medio Ambiente y Recursos Naturales: México, México, 2012. (In Spanish)

39. Selborne, L. The Ethics of Freshwater use: A Survey; UNESCO: Paris, France, 2000.

40. González Cabrera, N. Sobre la etica del Agua; Centro de Investigaciones y Servicios Ambientales: Madrid, Spain, 2003; pp. 109-116.

41. Sampford, C. Water Rights and Water Governance: A Cautionary Tale and a Case for Interdisciplinary Governance; Llamas, M.R., Martínez-Cortina, L., Mukherji, A., Eds.; Water Ethics, CRC Press/Balkema: Boca Raton, FL, USA, 2009; pp. 97-113.

42. Rhonheimer, M. La Perspectiva de la Moral; Fundamentos de la Ética Filosófica; Editorial Rialp: Madrid, Spain, 2007. (In Spanish)

43. Binetti, P. Etica e Democrazia. IL Contributo dei Cattolici Alla Politica; Edizioni Lindau: Torino, Italy, 2012. (In Italian) 
44. Solanes, M.; González-Villareal, F. The Dublin Principles for Water as Reflected in a Comparative Assessment of Institutional and Legal Arrangements for Integrated Water Resources Management; Global Water Partnership and Swedish International Development Cooperation Agency (SIDA): Stockholm, Sweden, 1999; pp. 19-26.

45. López-Gunn, E.; LLamas, M.R. Can Human Ingenuity, Science and Technology Help Solve the World's Problems of Water and Food Security? In Re-Thinking Water and Food Security; Martínez-Cortina, L., Garrido, A., López-Gunn, E., Eds.; CRC Press/Balkema: Boca Raton, FL, USA, 2009.

46. Jarvis, C.B.; Mackenzie, S.B.; Podsakoff, P.M. A critical review of construct indicators and measurement model misspecification in marketing and consumer research. J. Consum. Res. 2003, 30, 199-218. [CrossRef]

47. Cenfetelli, R.T.; Geneviève, B. Interpretation of Formative Measurement in Information Systems Research. MIS Q. 2009, 33, 689-708.

48. Hair, J.F.; Ringle, C.M.; Sarstedt, M. PLS-SEM: Indeed a silver bullet. J. Mark. Theory Pract. 2011, 19, 137-149. [CrossRef]

49. Peng, D.X.; Lai, F. Using partial least squares in operations management research: A practical guideline and summary of past research. J. Oper. Manag. 2012, 30,467-480. [CrossRef]

50. Ringle, C.M.; Wende, S.; Will, A. SmartPLS 2.0 (M3) Beta; University of Hamburg: Hamburg, Germany, 2005.

51. Haenlein, M.; Kaplan, A.M. A beginner's guide to partial least squares analysis. Underst. Stat. 2004, 3, 283-297. [CrossRef]

52. Sosik, J.J.; Kahai, S.S.; Piovoso, M.J. Silver bullet or voodoo statistics? A primer for using the partial least squares data analytic technique in group and organization research. Group Organ. Manag. 2009, 34, 5-36. [CrossRef]

53. Chin, W.W. The Partial Least Squares approach to structural equation modeling. In Modern Methods for Business Research; Marcoulides, G.A., Ed.; Lawrence Erlbaum Associates: Mahwah, NJ, USA, 1998; pp. 295-336.

54. Carmines, E.G.; Zeller, R.A. Reliability and Validity Assessment; Sage Publications: Thousand Oaks, CA, USA, 1979.

55. Nunnally, J.C.; Bernstein, I.H. The assessment of reliability. Psychom. Theory 1994, 3, 248-292.

56. Fornell, C.; Larcker, D.F. Evaluating structural equation models with unobservable variables and measurement error. J. Mark. Res. 1981, 18, 39-50. [CrossRef]

57. Cronbach, L.J. Coefficient alpha and the internal structure of a test. Psychometrika 1951, 16, 297-334. [CrossRef]

58. Churchill, G.A., Jr. A paradigm for developing better measures of marketing constructs. J. Mark. Res. 1979, 16, 64-73. [CrossRef]

59. Werts, C.E.; Linn, R.L.; Jöreskog, K.G. Intraclass reliability estimates: Testing structural assumptions. Educ. Psych. Meas. 1974, 34, 25-33. [CrossRef]

60. Stone, M. Cross-validatory choice and assessment of statistical predictions. J. R. Stat. Soc. 1974, 36, 111-133.

61. Geisser, S. The predictive sample reuse method with applications. J. Am. Stat. Assoc. 1975, 70, 320-328. [CrossRef]

(C) 2016 by the authors; licensee MDPI, Basel, Switzerland. This article is an open access article distributed under the terms and conditions of the Creative Commons Attribution (CC-BY) license (http://creativecommons.org/licenses/by/4.0/). 